\title{
Emulsifying activity of a biosurfactant produced by a marine bacterium
}

\author{
K. Abraham Peele ${ }^{1} \cdot$ V. Ravi Teja Ch. $^{2} \cdot$ Vidya P. Kodali $^{2}($ (D)
}

Received: 16 June 2016/ Accepted: 8 August 2016/Published online: 22 August 2016

(c) The Author(s) 2016. This article is published with open access at Springerlink.com

\begin{abstract}
Biosurfactants produced by biofilm-forming bacteria have great applications in biotechnology, pharmaceutical, food engineering, bioremediation, and biohydrometallurgy industries. This study aimed to find out the bacteria that produce novel exopolymers (EPSs) which can find potential role in oil biodegradation. A screening procedure was performed to detect EPS-producing bacteria. The EPS producing isolate was identified as Acinetobacter species by $16 \mathrm{~S}$ rDNA analysis. The polymer produced by the isolate has shown significant emulsification and surfactant activities, and the activities were compared to some of the commercial emulsifiers. The EPS has been partially characterized by FTIR analysis and has been proved to be a glycolipoprotein. This is one of the very few reports on Acinetobacter species producing EPS with surfactant properties.
\end{abstract}

Keywords Bioemulsifier · Biodegradation ·

Bioremediation · Hydrocarbon - Marine microbiology

$\begin{array}{ll}\text { Abbreviations } \\ \text { EPS } & \text { Exopolysaccharide } \\ \text { FTIR } & \text { Fourier transform infrared spectroscopy } \\ \text { PBS } & \text { Phosphate buffer saline } \\ \text { DAPI } & 4^{\prime}, \text { 6-Diamidino-2-phenylindole }\end{array}$

Vidya P. Kodali

kodalividyaprabhakar@gmail.com

1 Department of Biotechnology, Vignan's University, Vadlamudi, Guntur Dist., Andhra Pradesh, India

2 Department of Biotechnology, Vikrama Simhapuri University, Nellore Dist., Andhra Pradesh, India

\section{Introduction}

Biosurfactants are surface-active and structurally diverse group molecules that are synthesized by the microbial cells. Most of the surfactants being used are chemically synthesized. There is an observable increase in the interest among the scientists on microbial emulsifiers because of their potential applications in environmental protection, low toxicity, high biodegradability, and high foaming capacity. Bioemulsifiers get accumulated at the interphase between the two immiscible phases by which they can reduce the surface tension, thereby resulting in the increased solubility and emulsification of the immiscible phases. Bioemulsifiers can convert the insoluble substrate into soluble substrates which can be utilized by the microorganisms for their metabolism (Rodrigues et al. 2006). Biosurfactants with such surface properties stood as good examples for enhanced oil recovery (EOR). Some of the biosurfactants are very effective, and they can reduce the surface tension of water from 72 dynes/cm to value range of 25-30 dynes/cm (Satpute et al. 2010). Lipopeptides belong to a class of biosurfactants that have shown remarkable surface active properties, viz., surplus crude oil recovery, food processing, de-emulsification, antimicrobial, antitumor, antiviral, and anti adhesive activities (Bodour et al. 2004). Biosurfactants have been shown dispersant activity by reducing the surface tension of oilwater interface effectively. Many bacteria like Acinetobacter, Rhodococcus species, and Actinomycetes, and other biofilm forming bacteria have been reported to produce biosurfactants. However, there is only less abundance of biosurfactant producing microorganisms that can be grown in natural environments than in contaminated environments. Growth pattern and biofilm formation may depend on various development factors, such as surface area, 
smoothness, flow velocity, and nutrients (Donlan and Costerton 2002). Hence, this study aims to isolate and molecular characterize an emulsifier producing bacterium from marine source.

\section{Materials and methods}

\section{Isolation of EPS producer and biofilm assay}

The marine water samples were collected from Bay of Bengal at Bapatla, Andhra Pradesh. Serial dilutions were performed for the screening of bacteria with the highest EPS producing ability. These marine isolates were grown using Nutrient broth (Hi media, Mumbai). Tube staining method with crystal violet is used to test the biofilm producing ability of the microbes (Abraham et al. 2012; Fabres-Klein et al. 2015). The highest EPS producer was screened for biosurfactant activity and was characterized biochemically. Identification of the strain was carried out by $16 \mathrm{~S}$ r-DNA analyses.

\section{Staining and visualization of EPS with fluorescent labeled lectins}

For the visualization of EPS by sample M, glass slides were immersed in bacterial suspension and kept in Petri dishes for 7 days at $37{ }^{\circ} \mathrm{C}$ for the biofilm formation, then the glass slide surface is covered with $50 \mu \mathrm{l}$ DAPI solution for $15 \mathrm{~min}$, and then the slide was washed with $1 \mathrm{ml}$ PBS and distilled water. Treated slide was observed under fluorescence microscope (Carl Ziess) after drying (Pal and Paul 2013).

\section{Biosurfactant production and quantification}

The biosurfactant production was studied in Luria broth (LB) by growing sample $\mathrm{M}$ for 14 days under submerged conditions at various $\mathrm{pH}$ and temperature conditions. The supernatant was collected by centrifugation, dried, lyophilized, and analyzed for biosurfactant production by measuring total carbohydrate, lipid, and protein contents (Dubois et al. 1951; Lowry et al. 1951; Kodali and Sen 2008). The critical micelle concentration (CMC) of biosurfactant was measured in PBS buffer using K6 force tensiometer (Kruss, Germany) (Hayder et al. 2014).

\section{Emulsifying potential of the biosurfactant}

Emulsifying potential of the biosurfactant of sample $\mathrm{M}$ was found out against hydrocarbons such as (benzene and xylene), vegetable oils such as (olive and sunflower), and crude oils such as (kerosene, diesel, and petrol). All these hydrocarbons were of analytical grade (Fischer scientific, USA), and the rest of the oils were bought from local suppliers. The emulsifying activity was measured by combining equal volumes of biosurfactant solution $(1 \%$ $\mathrm{w} / \mathrm{v})$ and the hydrophobic substrates in 10-mm-diameter tubes, mixed on a vortex for $2 \mathrm{~min}$ and left to stand for 24, 96 and $168 \mathrm{~h}$ at $30^{\circ} \mathrm{C}$. Emulsifying activity was determined, and it is the percentage of the total height that was occupied by the emulsion after a time period of $24 \mathrm{~h}$ (Camacho-Chab et al. 2013).

\section{Thin-layer chromatography and FTIR analysis}

The biosurfactant was dissolved in methanol and spotted on a $10 \times 10 \mathrm{~cm}$ precoated silicagel GF 254 . Samples will be prepared by the homogeneous dispersal of $1 \mathrm{mg}$ of the biosurfactant sample, in pellets of potassium bromide, and now, these samples were subjected for FTIR analysis. IR

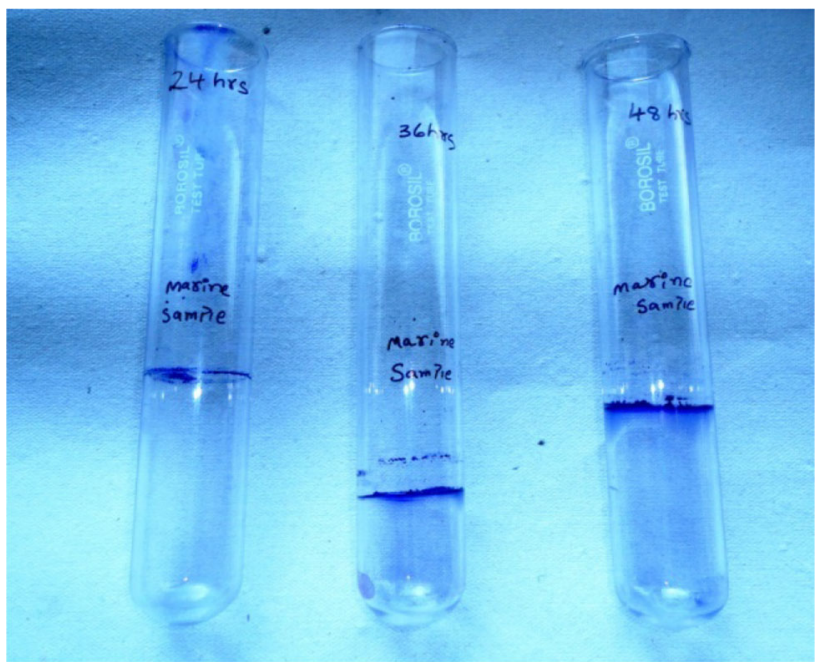

Fig. 1 Biofilm assay by crystal violet staining

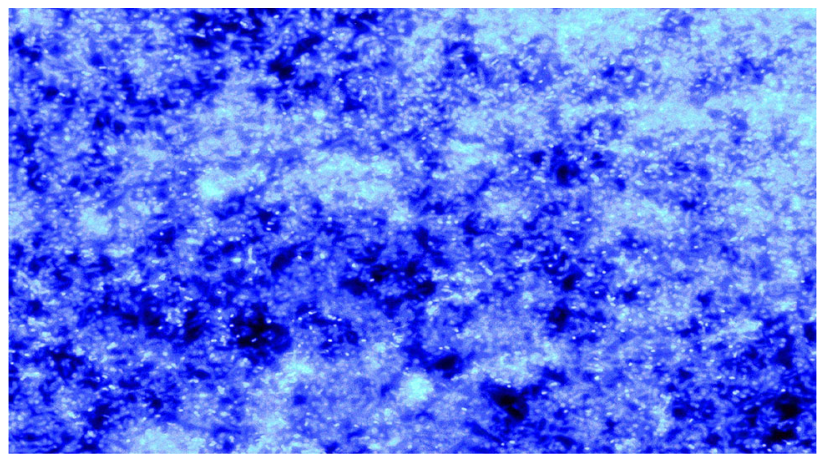

Fig. 2 Visualization of bacterial cells and biofilm EPS by staining with DAPI by fluorescence microscopy 

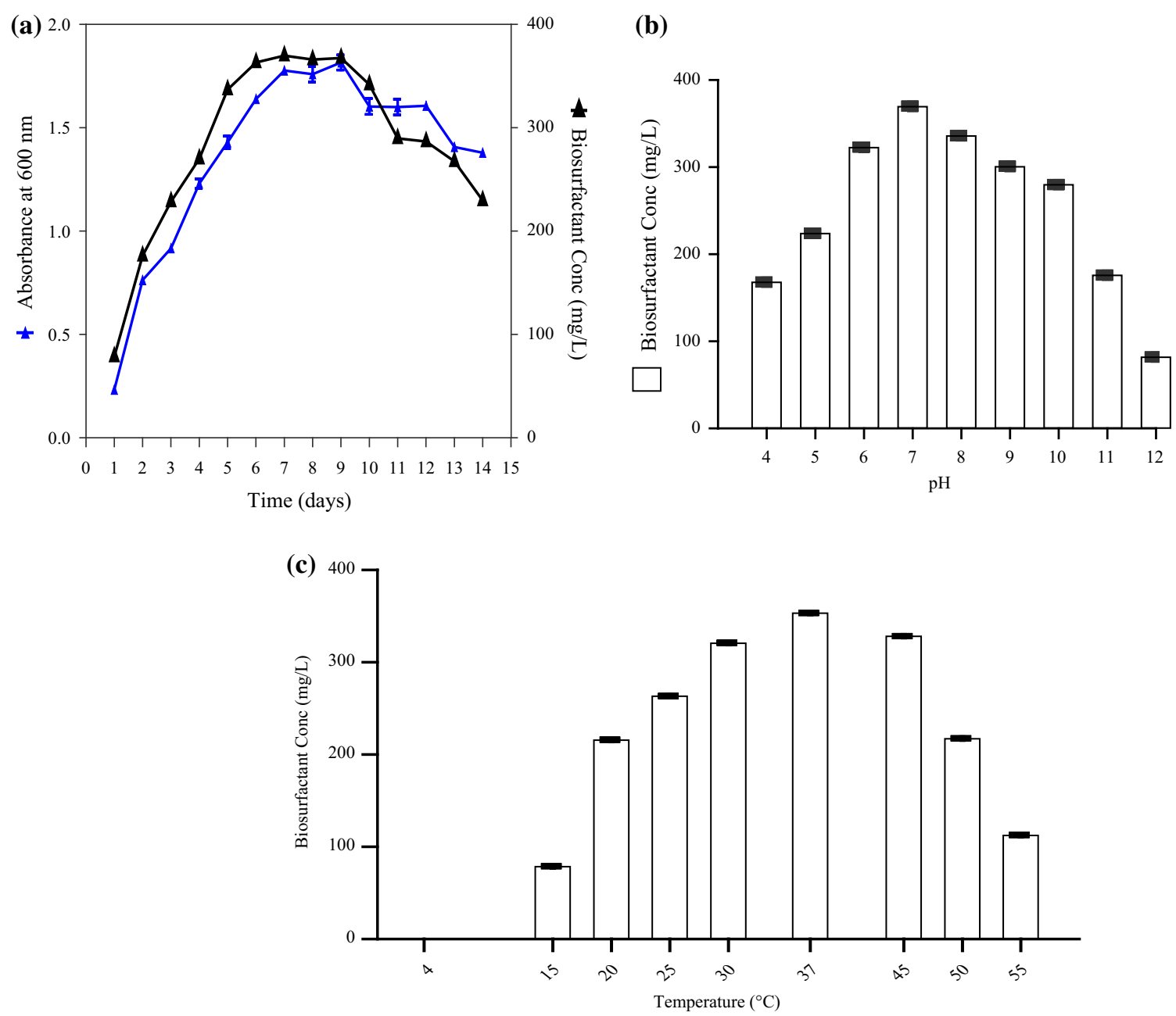

Fig. 3 a Time course (growth kinetics) of sample M produced biosurfactant. b Effect of $\mathrm{pH}$ on biosurfactant production by sample M. $\mathbf{c}$ Effect of temperature on biosurfactant production by sample $\mathrm{M}$

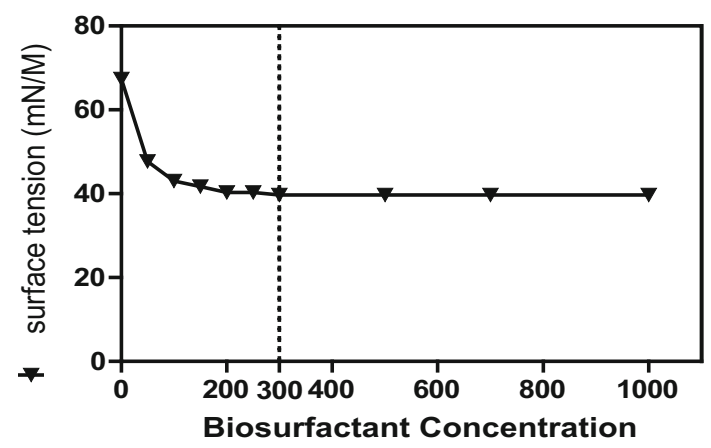

Fig. 4 Critical micelle concentration of bioemulsifier produced by sample $\mathrm{M}$

spectra were collected over the range of $400-4000 \mathrm{~cm}^{-1}$ and with a resolution of $4 \mathrm{~cm}^{-1}$ (Das et al. 2008; Thompson et al. 1994).

\section{S rDNA sequence analysis}

The 16S rDNA analysis of the sample $\mathrm{M}$ was analyzed. DNA purification kit (PureFast ${ }^{\circledR}$ Bacterial Genomic DNA kit), 16S Bac specific primer-forward (10 pico-moles $/ \mu \mathrm{L})$, and 16S Bac specific primer-reverse (10 pico-moles $/ \mu \mathrm{L})$ were used to amplify the $16 \mathrm{~S}$ rDNA gene by PCR. The PCR mixture contained $50-\mu \mathrm{L}$ final volume; $25 \mu \mathrm{L}$ of master mix contains $10 \mathrm{X}$ Taq buffer, $2 \mathrm{mM} \mathrm{MgCl}_{2}$, $0.4 \mathrm{mM}$ dNTPs mix, 2U Proofreading Taq DNA polymerase, and $1 \mu \mathrm{L}$ genomic DNA. The DNA amplification was performed using Eppendorf PCR, System. The PCR program was as follows: $94{ }^{\circ} \mathrm{C}$ for $1 \mathrm{~min}, 60{ }^{\circ} \mathrm{C}$ for $1 \mathrm{~min}$, and $72{ }^{\circ} \mathrm{C}$ for $1 \mathrm{~min}$ for 30 cycles each of $6 \mathrm{~min}$ at $72{ }^{\circ} \mathrm{C}$. The PCR products were visualized under UV light after electrophoresis on a $2 \%(\mathrm{w} / \mathrm{v})$ agarose gel containing ethidium bromide. The PCR product was sent to Helini Biomolecules for sequence analysis. The nucleotide 
Table 1 Emulsifying activity of biosurfactant, synthetic surfactants, and bioemulsifiers on various hydrophobic substrates after $168 \mathrm{~h}$ of incubation at $30^{\circ} \mathrm{C}$

\begin{tabular}{|c|c|c|c|c|c|}
\hline \multirow[t]{2}{*}{$\begin{array}{l}\text { Hydrophobic } \\
\text { substrate }\end{array}$} & \multirow[t]{2}{*}{$\begin{array}{l}\text { Emulsifying activity } \\
\text { of Biosurfactant }\end{array}$} & \multicolumn{2}{|c|}{$\begin{array}{l}\text { Emulsifying activity } \\
\text { of Synthetic surfactants }\end{array}$} & \multicolumn{2}{|c|}{$\begin{array}{l}\text { Emulsifying activity } \\
\text { of Biopolymers }\end{array}$} \\
\hline & & Tween 20 & Triton X-100 & Gum arabic & Xanthan gum \\
\hline Xylene & $74 \pm 0.91$ & $94 \pm 0.72$ & $95 \pm 0.96$ & $78 \pm 1.16$ & $78 \pm 1.19$ \\
\hline Benzene & $67 \pm 1.42$ & $94 \pm 0.97$ & $68 \pm 0.70$ & $82 \pm 2.13$ & $72 \pm 1.35$ \\
\hline Toluene & $71 \pm 0.97$ & $82 \pm 0.24$ & $81 \pm 1.93$ & $70 \pm 1.85$ & $70 \pm 3$ \\
\hline Diesel & $76 \pm 1.23$ & $73 \pm 0.37$ & $68 \pm 2$ & $89 \pm 0.48$ & $89 \pm 1.2$ \\
\hline Petrol & $78 \pm 0.78$ & $68 \pm 2.2$ & $72 \pm 0.67$ & $88 \pm 0.84$ & $87 \pm 3$ \\
\hline Kerosene & $67 \pm 0.82$ & $67 \pm 1.46$ & $69 \pm 0.25$ & $78 \pm 0.87$ & $75 \pm 0.89$ \\
\hline Motor oil & $81 \pm 0.94$ & $69 \pm 1.32$ & $67 \pm 0.49$ & $93 \pm 0.71$ & $91 \pm 0.75$ \\
\hline Olive oil & $73 \pm 2.05$ & 100 & 100 & $99 \pm 0.49$ & $83 \pm 0.84$ \\
\hline Sunflower oil & $76 \pm 0.89$ & 100 & $98 \pm 0.82$ & $98 \pm 0.2$ & $86 \pm 0.41$ \\
\hline
\end{tabular}

sequence of the 16S rDNA genes (about 1400 nucleotides each) was aligned using CLUSTAL W program (Thompson et al. 1994).

\section{Results and discussion}

\section{Isolation and screening of EPS producer}

From six isolates, one isolate was selected based on its highest EPS (Biofilm) producing ability (Fig. 1), named sample M, and was characterized biochemically. The isolate was positive for catalase, laccase, and lactase tests, and negative for starch hydrolysis, methyl red and VogesProskauer, indole production, utilization of citrate, urease production, and hydrogen sulfide production tests. In drop collapsing test, a flat drop and, in oil displacement method, a clear zone were observed (Andreoni et al. 2000; Rodrigues et al. 2006).

\section{Staining and visualization of EPS with fluorescently labeled lectins}

The biofilm of sample $M$ was stained with DAPI and visualized by fluorescence microscope (Fig. 2) DAPI stains the cells and extracellular matrix by passing through the cell membrane and allows the microscopic detection of the biofilm.

\section{Biosurfactant production and quantification}

The biosurfactant produced by sample $M$ was extracted and dissolved in $1 \mathrm{ml}$ of demineralized water. The total carbohydrate and protein concentrations were observed to be 310 and $150 \mu \mathrm{g} / \mathrm{ml}$, respectively. Sample $\mathrm{M}$ showed maximum biosurfactant production at $\mathrm{pH} 7.0$ and $37^{\circ} \mathrm{C}$
(Fig. 3). The addition of biosurfactant at the concentration of $300 \mathrm{mg} / \mathrm{l}$ to PBS buffer and CMC reduced the surface tension value to 39 and of $39 \mathrm{mN} / \mathrm{m}$, respectively (Fig. 4) (Kokare et al. 2007; Khopade et al. 2012).

\section{Emulsifying potential of the biosurfactant}

The emulsifying activity of biosurfactant from sample $\mathbf{M}$ was tested against different hydrocarbon substrates. The emulsifying activity of biosurfactant was evaluated after 24, 96, and $168 \mathrm{~h}$. The emulsions found to be stable even after 7 days. Synthetic surfactants Triton X-100 and Tween 20 were more efficient than biosurfactant, and the two

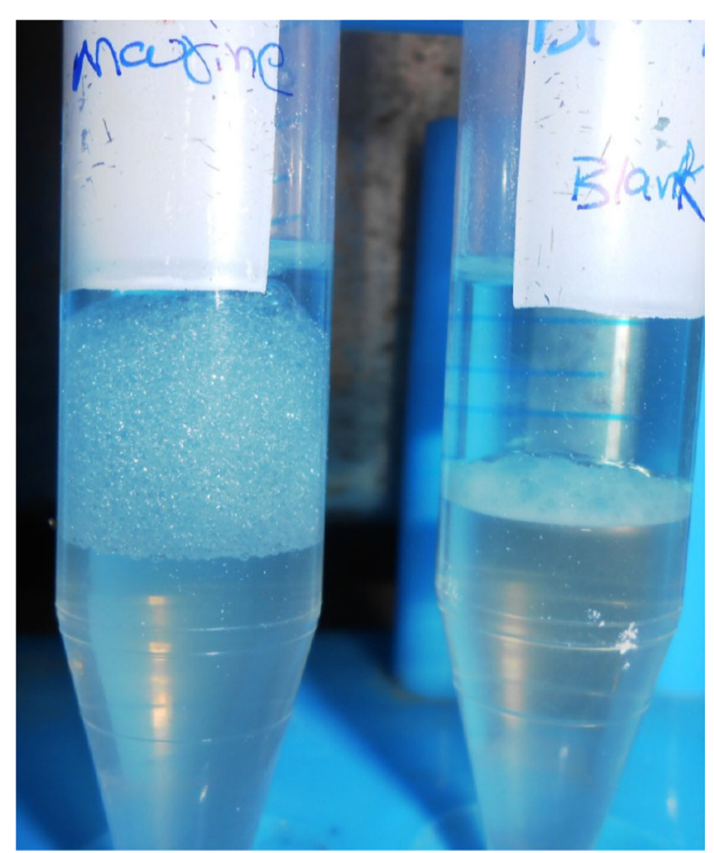

Fig. 5 Emulsification potential of bioemulsifier in kerosene (1\% $\mathrm{w} / \mathrm{v})$ at $24 \mathrm{~h}$ 
Fig. 6 FTIR analysis of biosurfactant produced by sample $\mathrm{M}$

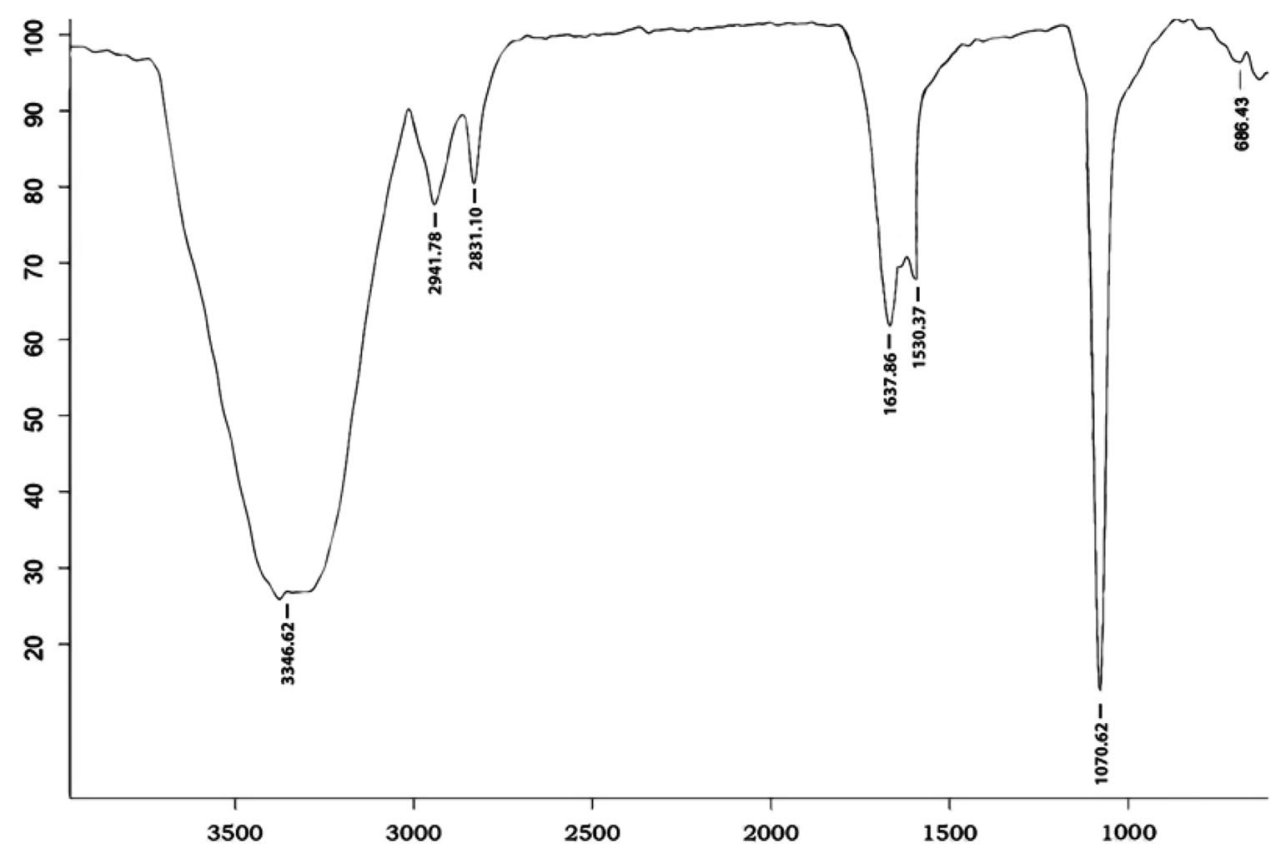

Thin-layer chromatography and FTIR analysis

The ninhydrin solution and anthrone reagent developed plates showed the confirmation of peptides and lipids as red and yellow spots giving the preliminary analysis of the biosurfactant extracted from sample $\mathrm{M}$ are lipopeptide in nature. The FTIR spectrum of the biosurfactant produced by sample $M$ showed a broad $\mathrm{O}-\mathrm{H}$ stretching band at $3346 \mathrm{~cm}^{-1}$ and at an intense band at $1070 \mathrm{~cm}^{-1}$ which is an indicative for typical of carbohydrates. In addition, bands at 1637 and $1530 \mathrm{~cm}^{-1}$ indicating (Fig. 6) the presence of lipids, shown by the peak at $2941 \mathrm{~cm}^{-1}$ in the FT-IR analysis represent the asymmetric stretch $(\mathrm{C}-\mathrm{H})$ of $-\mathrm{CH}_{2}$ groups combined with that of $-\mathrm{CH}_{3}$ groups in lipids. The presence of lipid content carbohydrates and proteins suggests that biosurfactant of sample $\mathrm{M}$ was a class of glycolipoprotein (Fig. 7) (Bergey and Holt 1994).

\section{S rDNA sequence analysis}

The phylogenetic position of sample $\mathrm{M}$ based on its $16 \mathrm{~S}$ rDNA gene confirmed that its closest relative was Acinetobacter genus (Fig. 8). However, definitive species identification of this bacterial isolate requires an approach including biochemical, physiological, and nucleic acidbased methods (Stackebrandt and Ebers 2006).

\section{Statistical studies}

All experiments were conducted in triplicate and analyzed with ANOVA, $t$ test using Graph Pad Prism 5 software. Results represent standard error mean.

a good emulsifier (Fig. 5). 


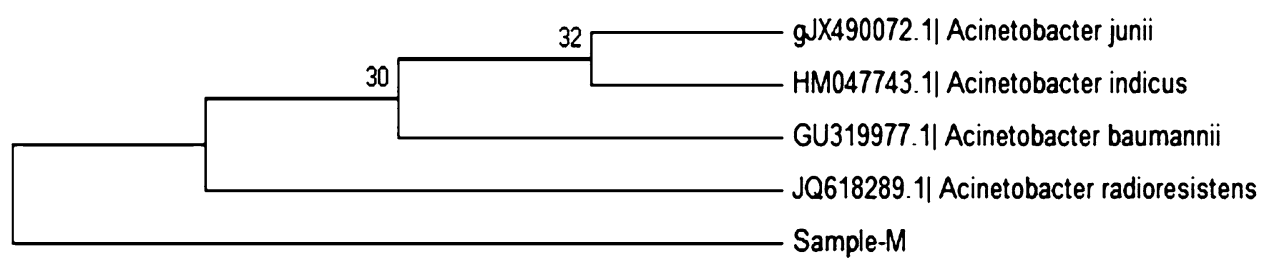

Fig. 8 Phylogenetic tree based on 16S rDNA gene sequences, showing the positions of strain sample M (Acinetobacter M6, Accession no: KR559749) relative to all known Acinetobacter species. Accession numbers of 16S rDNA gene sequences of reference organisms are also shown

\section{Conclusion}

From the above observation, it was concluded that our marine isolate, sample-M which was identified as Acinetobacter genus and was submitted to GenBank as Acinetobacter M6. The isolate produced a surfactant which was composed of glycolipoprotein. The experimental results showed that the biosurfactant has good surface active properties which could be developed into a promising molecule for industrial and environmental applications. Maximum biosurfactant production was observed in 7 days of incubation. The functional stability of this bioemulsifier was retained for long periods of time. This study extends a great knowledge on marine bacteria that produce biopolymers.

Acknowledgments Dr. KVP acknowledges Department of Biotechnology (DBT, Govt. of India) for the financial support to carry out this research (Project No. BT/PR7932/AAQ/3/642/2013). Authors also thankful to Vikrama Simhapuri University, Nellore, India and Vignan's University, Guntur for providing facilities.

\section{Compliance with ethical standards}

Conflict of interest The authors declare that they have no conflict of interest regarding the publication of this manuscript.

Open Access This article is distributed under the terms of the Creative Commons Attribution 4.0 International License (http:// creativecommons.org/licenses/by/4.0/), which permits unrestricted use, distribution, and reproduction in any medium, provided you give appropriate credit to the original author(s) and the source, provide a link to the Creative Commons license, and indicate if changes were made.

\section{References}

Abraham KP, Sreenivas J, Venkateswarulu TC, Indira M, Babu DJ, Diwakar T, Prabhakar KV (2012) Investigation of the potential antibiofilm activities of plant extracts. Int J Pharm Pharm Sci 4(4):282-285

Andreoni V, Luischi MM, Cavalca L, Erba D, Ciappellano S (2000) Selenite tolerance and accumulation in the Lactobacillus species. Ann Microbiol 50(1):77-88

Bergey DH, Holt JG (1994) Bergey's manual of determinative bacteriology. Williams and Wilkins, Baltimore, p 787

Bodour AA, Guerrero-Barajas C, Jiorle BV, Malcomson ME, Paull AK, Somogyi A, Trinh LN, Bates RB, Maier RM (2004) Structure and characterization of flavolipids, a novel class of biosurfactants produced by Flavobacterium sp. strain MTN11. Appl Environ Microbiol 70(1):114-120

Camacho-Chab JC, Guézennec J, Chan-Bacab MJ, Ríos-Leal E, Sinquin C, Muñiz-Salazar R, De la Rosa-García SDC, ReyesEstebanez M, Ortega-Morales BO (2013) Emulsifying activity and stability of a non-toxic bioemulsifier synthesized by Microbacterium sp. MC3B-10. Int J Mol Sci 14(9):18959-18972

Das P, Mukherjee S, Sen R (2008) Antimicrobial potential of a lipopeptide biosurfactant derived from a marine Bacillus circulans. J Appl Microbiol 104(6):1675-1684

Donlan RM, Costerton JW (2002) Biofilms: survival mechanisms of clinically relevant microorganisms. Clin Microbiol Rev 15(2):167-193

Dubois M, Dubois M, Gilles K, Hamilton JK, Rebers PA, Smith F (1951) A colorimetric method for the determination of sugars. Nature 168:167. doi:10.1038/168167a0

Fabres-Klein MH, Santos MJC, Klein RC, de Souza GN, Ribon ADOB (2015) An association between milk and slime increases biofilm production by bovine Staphylococcus aureus. BMC Vet Res 11(1):3. doi:10.1186/s12917-015-0319-7

Hayder NH, Alaa S, Abdulmalik H (2014) Optimized conditions for bioemulsifier production by local Streptomyces sp. SS 20 isolated from hydrocarbon contaminated soil. Rom Biotechnol Lett 19(1):8979-8993

Khopade A, Ren B, Liu X-Y, Mahadik K, Zhang L, Kokare C (2012) Production and characterization of biosurfactant from marine Streptomyces species B3. J Colloid Interface Sci 367(1):311-318

Kodali VP, Sen R (2008) Antioxidant and free radical scavenging activities of an exopolysaccharide from a probiotic bacterium. Biotechnol J 3(2):245-251

Kokare CR, Kadam SS, Mahadik KR, Chopade BA (2007) Studies on bioemulsifier production from marine Streptomyces sp. S1. Indian J Biotechnol 6:78-84

Lowry OH, Rosebrough NJ, Farr AL, Randall RJ (1951) Protein measurement with the Folin phenol reagent. J Biol Chem 193(1):265-275

Pal A, Paul AK (2013) Optimization of cultural conditions for production of extracellular polymeric substances (EPS) by Serpentine Rhizobacterium Cupriavidus pauculus KPS 201. J Polym. Article ID 692374:1-7. doi:10.1155/2013/692374

Rodrigues LR, Teixeira JA, Vander Mei HC, Oliveira R (2006) Physicochemical and functional characterization of a biosurfactant produced by Lactococcus lactis 53. Colloids Surf B 49(1):79-86

Satpute SK, Banat IM, Dhakephalkar PK, Banpurkar AG, Chopade BA (2010) Biosurfactants, bioemulsifiers and exopolysaccharides from marine microorganisms. Biotechnol Adv 28(4):436-450

Stackebrandt E, Ebers J (2006) Taxonomic parameters revisited: tarnished gold standards. Microbiol Today 33:152-155

Thompson JD, Higgins DG, Gibson TJ (1994) CLUSTAL W: improving the sensitivity of progressive multiple sequence alignment through sequence weighting, position-specific gap penalties and weight matrix choice. Nucl Acids Res 22(22):4673-4680 